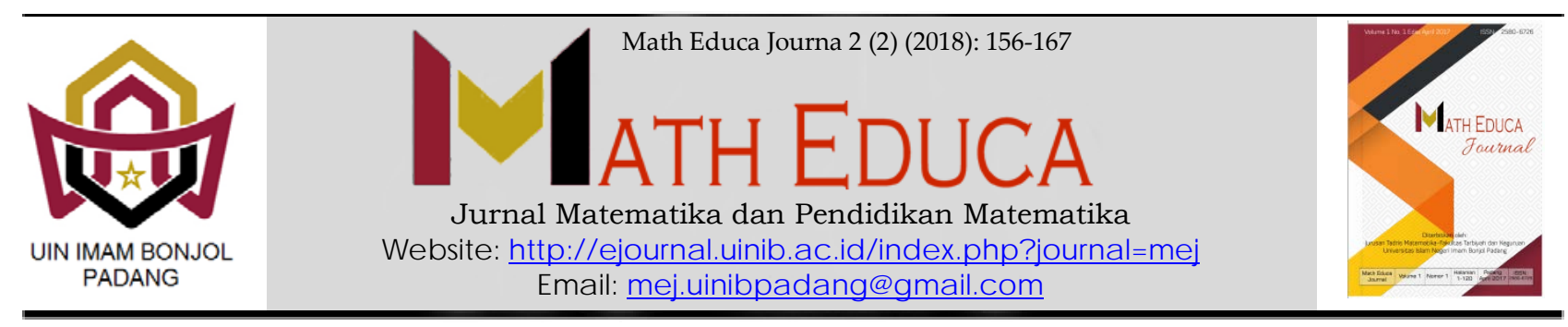

\title{
Kesalahan Koneksi Matematis Peserta Didik Menjawab Soal Materi Kesebangunan dan Kekongruenan Kelas IX SMPN 4 VII Koto Sungai Sarik Kabupaten Padang Pariaman
}

\author{
${ }^{1}$ Nursaliyah, ${ }^{2}$ Andi Susanto \\ Tadris Matematika, Fakultas Tarbiyah dan Keguruan, UIN Imam Bonjol Padang, Indonesia \\ Nursaliyah@yahoo.com,soulmath_andi@yahoo.co.id
}

Rec eived: August 2018; Accepted: September 2018; Published: October 2018

\begin{abstract}
Abstrak
Penelitian ini bertujuan mengetahui proporsi dan penyebab terjadinya kesalahan koneksi matematis yang dilakukan peserta didik menjawab soal materi kesebangunan dan kekongruenan kelas IX SMPN 4 VII Sungai Sarik Kabupaten Padang Pariaman. Jenis penelitian ini adalah deskriptif dengan pendekatan kualitatif. Subjek penelitian adalah peserta didik kelas IX $\mathrm{X}_{3}$ tahun ajaran 2017/2018, yang diambil dari 6 peserta didik yang melakukan kesalahan koneksi matematis, 2 peserta didik dari kelompok atas, 2 kelompok menengah dan 2 kelompok bawah. Hasil penelitian menunjukkan bahwa: a) Kesalahan koneksi antar topik matematika rata-rata 18,83. Penyebabnya peserta didik belum mampu menghubungkan pengetahuanpengetahuan yang dimiliki, kurang memahami dan lupa konsep, tidak memahami soal, kurang teliti dan kesalahan dalam perhitungan. b) Kesalahan koneksi antar disiplin ilmu lain rata-rata 68,34. Penyebabnya peserta didik belum mampu menghubungkan pengetahuan antar disiplin ilmu lain, kurang teliti dalam menyimak dan mengenali persoalan berkaitan dengan pokok bahasan tertentu dan melihat keterangan dari soal. c) Kesalahan koneksi matematika dengan masalah dalam kehidupan sehari-hari rata-rata 81,67. Penyebabnya peserta didik sulit memahami soal, rendahnya penguasaan materi prasyarat, tidak mampu mengaitkan matematika dengan kehidupan sehari-hari.
\end{abstract}

Kata Kunci : Kesalahan Koneksi Matematis, Kesebangunan dan Kekongruenan

\section{PENDAHULUAN}

Hasil belajar merupakan salah satu indikator keberhasilan peserta didik dalam menempuh pendidikan di sekolah atau pendidikan formal lainnya. Hasil belajar juga bisa diartikan sebagai kemampuan yang diperoleh peserta didik setelah melalui kegiatan belajar. Pecerta didik dikatakan ${ }^{*}$ Corresponding author. Peer review under responsibility UIN Imam Bonjol Padang. (c) 2018 UIN Imam Bonjol Padang. All rights reserved.

p-ISSN: 2580-6726

e-ISSN: 2598-2133 berhasil dalam belajar matematika, apabila peserta didik telah memahami konsep-konsep dan terampil mengerjakan soal-soal yang berhubungan dengan konsep yang disajikan, serta mampu mengaplikasikan konsep-konsep tersebut ke dalam situasi yang lainnya.

Menurut Waslisman sebagaimana yang dikutin oleh Susanto (ว012: 1)) menoratakan 
bahwa faktor-faktor yang mempengaruhi hasil belajar adalah 1) Faktor interrnal; merupakan faktor yang bersumber dari dalam diri peserta didik yang mempengaruhi kemampuan belajarnya. faktor ini meliputi: kecerdasan, minat dan perhatian, motivasi belajar, ketekunan, sikap, kebiasaan belajar serta kondisi fisik dan kesehatan. 2) Faktor eksternal; merupakan faktor yang berasal dari luar diri peserta didik yang mempengaruhi hasil belajar yaitu; keluarga, sekolah, dan masyarakat.

Hasil belajar yang dicapai oleh peserta didik akan berbeda satu sama lain, hal ini di sebabkan berbagai faktor baik internal maupun eksternal seperti yang diuraikan di atas. Tinggi rendahnya capaian hasil belajar bisa berasal selama proses belajar atau pada saat evaluasi terjadi seperti saat ujian. Tinggi rendahnya hasil belajar dapat di jadikan sebagai sebuah indikator apakah seorang peserta didik mengalami kesulitan dalam belajar khususnya hasil belajar rendah.

Salah satu faktor penyebab rendahnya hasil belajar peserta didik adalah masih banyak peserta didik yang melakukan kesalahan dalam menjawab soal. Salah satu jenis kesalahan yang dilakukan peserta didik dalam menjawab soal adalah kesalahan koneksi matematis.

Menurut NCTM (2000: 29) “terdapat lima kemampuan dasar matematika yang merupakan standar, yaitu pemecahan masalah (problem solving), penalaran dan pembuktian (reasoning and proof), komunikasi (communication), koneksi (connections), dan representasi (representation)".

Menurut Kusuma dan Rohendi sebagaimana yang dikutip oleh Rahardjo (2016 : 378)" kemampuan koneksi matematis adalah kemampuan seseorang dalam menyajikan hubungan internal dan eksternal dalam matematika yang meliputi koneksi antara topik matematika, koneksi matematika dengan disiplin ilmu lain, dan koneksi matematika dalam kehidupan sehari-hari.

Menurut Hurs (2004: 440) "konsepkonsep dalam matematika memiliki keterkaitan antara satu dengan yang lainnya, oleh karena itu dalam memecahkan masalah matematika seseorang dapat menghubungkan satu konsep dengan konsep yang lain”. Rohendi \& Dulpaja (2003: 17) menyatakan bahwa "dengan koneksi matematis, peserta didik dapat menghubungkan ide-ide matematis yang akan memfasilitasi kemampuan peserta didik untuk merumuskan dan memverifikasi dugaan antara topik dalam matematika". Tanpa koneksi matematis maka peserta didik harus belajar dan mengingat terlalu banyak konsep dan prosedur matematika yang saling terpisah (NCTM, 2000:275).

Kenyataannya, masih banyak peserta didik yang melakukan kesalahan dalam membuat koneksi matematis karena kemampuan koneksi matematis peserta didik masih rendah. Hasil pekerjaan peserta didik masih belum sesuai dengan prosedur penyelesaian yang diajarkan.Banyak peserta 
didik belum bisa mengkaitkan konsep-konsep yang telah dipelajari sebelumnya dalam pemecahan masalah yang berkaitan dengan topik pelajaran yang sedang dipelajari, sehingga peserta didik mengalami kesulitan dalam menyelesaikan soal-soal yang diberikan oleh pendidik mata pelajaran matematika. Jika peserta didik selalu mengalami kesulitan dalam pemecahan masalah yang diberikan, ini akan berdampak terhadap hasil belajar peserta didik.

Penyebab terjadinya kesalahan yang dilakukan oleh peserta didik adalah karena belum mampu menghubungkan pengetahuanpengetahuan yang dimiliki sebelumnya untuk mengerjakan soal, tingkat penguasaan materi serta pengetahuan prasyarat peserta didik masih kurang. Peserta didik belum mampu mengkaitkan konsep matematika yang ada hubungannya dengan masalah yang akan diselesaikan. Hal ini terjadi karena peserta didik belum mampu menghubungkan pengetahuanpengetahuan yang dimiliki untuk mengerjakan soal dan kurang memiliki ketelitian dalam menyimak dan mengenali sebuah persoalan atau soal-soal yang berkaitan dengan pokok bahasan tetentu.

Kesalahan yang dilakukan peserta didik apabila tidak dianalisis, maka kesalahan tersebut akan terus berlanjut sampai kapanpun. Analisis diperlukan untuk mengetahui letak, jenis dan penyebab kesalahan yang dilakukan peserta didik dalam menyelesaikan soal. Dengan mengetahui hal ini, maka pendidik dapat mengetahui apa yang dibutuhkan peserta didik untuk meningkatkan kemampuan koneksi matematis peserta didik dalam menyelesaikan soal. Setelah diketahui kesalahan koneksi matematis adalah salah satu jenis kesalahan yang dilakukan peserta didik, maka hal yang harus dilakukan pendidik adalah merancang kegiatan pembelajaran yang bisa menfasilitasi dan memberikan kesempatan kepada peserta didik untuk banyak melakukan koneksi matematis. Selain itu, hal ini juga menjadi acuan bagi pendidik dalam membiasakan peserta didik mengenal dan menerapkan koneksi matematis dalam menyelesaikan masalah matematika, sebagai bahan pertimbangan bagi pendidik dalam memilih strategi pembelajaran yang dapat meningkatkan kemampuan koneksi matematis peserta didik, sehingga kesalahan koneksi matematis peserta didik dapat diatasi.

\section{METODE PENELITIAN}

\section{Jenis Penelitian}

Penelitian ini termasuk dalam jenis penelitian deskriptif dengan pendekatan kualitatif. Penelitian ini mendeskripsikan proporsi kesalahan koneksi matematis yang dilakukan peserta didik dalam menjawab soal materi kesebangunan dan Kekongruenan, dan mengali penyebab kesalahan yang dilakukan peserta didik sesuai kondisi jawaban yang diberikan oleh peserta didik.

\section{Subjek Penelitian}

Populasi Subjek dalam penelitian ini adalah adalah seluruh peserta didik kelas $\mathrm{IX}_{3}$ yang terdaftar pada semester I tahun ajaran 2017/2018. Subjek penelitan yang dijadikan 
sumber data kualitatif terdiri dari 6 peserta didik yang melakukan kesalahan koneksi matematis. Subjek penelitian ini terdiri dari 2 peserta didik dari kelompok atas, 2 peserta didik dari kelompok menengah dan 2 peserta didik dari kelompok bawah. Pengumpulan data dilakukan melalui tes untuk mengetahui proporsi kesalahan koneksi matematis yang dilakukan peserta didik dalam menjawab soal pada materi kesebangunan dan kekongruenan kelas IX ${ }_{3}$ SMPN 4 VII Sungai Sarik Kabupaten Padang Pariaman. Hasil tes yang diperoleh diurutkan berdasarkan nilai peserta didik dimulai dari peserta didik yang memperoleh nilai tertinggi hingga yang terendah. Setelah diperoleh rata-rata dan simpangan baku dari data tersebut peserta didik dibagi tiga kelompok, yaitu peserta didik yang memiliki tingkat kemampuan atas, tingkat kemampuan menengah, dan tingkat kemampuan bawah.

\section{Waktu dan Tempat Penelitian}

Penelitian ini bertempat di SMPN 4 VII koto Sungai Sarik Kabupaten Padang Pariaman pada tanggal 15 Agustus 2017 sampai dengan 22 Agustus 2017. Pelaksanaan tes dilaksanakan hari selasa tanggal 15 Agustus 2017 pada jam pelajaran pertama pukul 07.20o8.40 sedangkan wawancara dilakukan pada hari selasa tanggal 22 Agustus 2017 pada jam pelajaran pertama pukul 07.20-08.40.
Variabel

Variabel merupakan segala sesuatu yang akan menjadi objek penelitian. Adapun yang menjadi variabel dalam penelitian ini adalah: kesalahan koneksi matematis yang dilakukan peserta didik dalam menjawab soal pada materi kesebangunan dan kekongruenan.

\section{Jenis dan Sumber Data}

Data adalah informasi yang akan diolah yang diperlukan untuk menguji hipotesis atau untuk menjawab pertanyaan penelitian.

1) Data Primer

Data primer yaitu data yang diperoleh langsung oleh peneliti dari responden. Data primer pada penelitian ini berupa hasil kerja atau lembar jawaban tes kemampuan koneksi matematis peserta didik dan hasil wawancara dengan peserta didik dalam bentuk transkip wawancara.

2) Data Sekunder

Data sekunder yaitu data yang diperoleh dari pendidik mata pelajaran matematika kelas IX ${ }_{3}$ SMPN 4 VII Koto Sungai Sarik berupa nilai tes awal materi kesebangunan dan kekongruenan, data hasil observasi, foto-foto kegiatan, dan lain-lain.

\section{Prosedur}

Secara umum prosedur penelitian ini terdiri dari tiga tahap yaitu tahap persiapan, tahap pelaksanaan dan tahap penyelesaian.

\section{Tahap Persiapan}

Sebelum kegiatan berlangsung maka terlebih dahulu penulis 
160 Math Educa Journal Volume 2 No. 2 Edisi Oktober 2018, pp. 156-167

mempersiapkan segala sesuatu yang berhubungan dengan pelaksanaan penelitian yaitu :

a. Menentukan lokasi penelitian.

b. Melakukan observasi dan wawancara dengan pendidik matematika peserta didik kelas IX SMPN 4 VII Koto Sungai Sarik.

c. Menemukan masalah di kelas IX $_{3}$ SMPN $4_{4}$ VII Koto Sungai Sarik.

d. Menyusun proposal penelitian.

e. Melakukan seminar proposal penelitian.

f. Menyusun instrumen penelitian (kisi-kisi, soal tes koneksi matematis dan kunci jawaban, instrumen wawancara).

g. Konsultasi instrumen penelitian dengan Dosen Pembimbing dan Tim Validator.

h. Meminta surat izin penelitian.

\section{Tahap Pelaksanaan}

a. Menetapkan kelas yang menjadi subjek penelitian.

b. Memberikan tes kemampuan koneksi matematis yang sudah divalidasi kepada peserta didik kelas IX $_{3}$ SMPN 4 VII Koto Sungai Sarik.

c. Menentukan subjek wawancara sebanyak enam peserta didik dengan mengklasifikasikan peserta didik terlebih dahulu menjadi tiga kelas yaitu kelompok atas, kelompok menengah dan kelompok bawah berdasarkan hasil tes kemampuan koneksi matematis.

d. Melakukan wawancara dengan peserta didik untuk mendapatkan informasi yang lebih mendalam mengenai jawaban peserta didik.

\section{Tahap Penyelesaian}

a. Mengumpulkan seluruh data dari lapangan yakni tes tertulis, hasil wawancara dan hasil observasi selama penelitian.

b. Melakukan analisis terhadap lembar jawaban peserta didik dan hasil wawancara.

c. Menafsirkan dan membahas hasil analisis data.

d. Menarik kesimpulan dari hasil analisis data.

e. Menyusun laporan hasil penelitian.

\section{Intrumen dan Teknik Pengumpulan Data}

Instrumen dalam penelitian ini adalah tes dan wawancara. Tes yang digunakan adalah tes kemampuan koneksi matematis berbentuk uraian yang terdiri dari 6 buah soal sesuai dengan jenis-jenis koneksi matematis, yakni soal nomor 1 dan 2 koneksi antar topik matematika, soal nomor 3 dan 4 koneksi antar disiplin ilmu lain dan soal nomor 5 dan 6 koneksi matematika dengan masalah dalam kehidupan sehari-hari. Penulis menganalisis jawaban peserta didik dan hasil wawancara dengan peserta didik terkait jawaban peserta didik untuk memperoleh informasi yang tidak didapatkan dari lembar jawaban peserta didik dan memperoleh data yang lebih valid dari apa yang telah dikerjakan peserta didik. 


\section{Teknik Analisis Data}

Adapun langkah-langkah analisis data dalam rangka mengumpulkan data dilakukan dalam tiga alur kegiatan yaitu:

a. Reduksi Data

Mereduksi data berarti merangkum, memilih hal-hal yang pokok dan memfokuskan pada hal-hal yang penting. Dengan demikian data yang telah direduksi akan memberikan gambaran yang lebih jelas dan mempermudah peneliti untuk melakukan pengumpulan data selanjutnya dan mencarinya bila diperlukan.

Tahap reduksi data dalam penelitian ini adalah :

1) Mengoreksi dan memberi skor serta rata-rat lembar jawaban peserta didik dan menentukan peserta didik yang dijadikan subjek penelitian.

2) Menganalisis lembar jawaban dan hasil wawancara peserta didik yang menjadi subjek penelitian sehingga diketahui proporsi kesalahan koneksi matematis yang dilakukan peserta didik dan penyebab terjadinya kesalahan koneksi matematis dalam menjawab soal pada materi kesebangunan dan kekongruenan kelas IX ${ }_{3}$ SMPN 4 VII Koto Sungai Sarik Kabupaten Padang Pariaman.

b. Penyajian Data

Pada penelitian kualitatif, penyajian data dapat dilakukan dalam bentuk uraian singkat, bagan, hubungan antar kategori flowehart dan sejenisnya. Dalam penyajian data ini dilengkapi dengan analisis data yang meliputi analisis hasil tes dan analisis hasil wawancara.

Penelitian ini menggunakan penyajian data uraian singkat dalam bentuk teks bersifat naratif. Kegiatan ini memunculkan dan menunjukkan kumpulan data atau informasi yang terorganisasi dan terkategori yang memungkinkan suatu penarikan kesimpulan dan tindakan. Dari hasil penyajian data dilakukan analisis. Kemudian disimpulkan berupa data temuan sehingga mampu menjawab permasalahan dalam penelitian ini.

c. Penarikan Kesimpulan

Penarikan kesimpulan adalah analisis data yang dilakukan secara terus menerus baik selama berlangsung penelitian di lapangan maupun sesudah pengumpulan data dan penyajian data. Untuk mengarah pada hasil kesimpulan ini tentunya berdasarkan hasil analisis data yang berasal dari tes dan wawancara.

Penarikan kesimpulan dari penelitian ini adalah proporsi kesalahan koneksi matematis yang dilakukan peserta didik dan penyebab terjadinya kesalahan koneksi matematis dalam menjawab soal pada materi kesebangunan dan

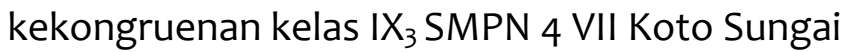
Sarik Kabupaten Padang Pariaman.

\section{HASIL PENELITIAN DAN PEMBAHASAN}

Berdasarkan lembar jawaban peserta didik yang mengikuti tes kemampuan koneksi matematis dapat diketahui persentase kesalahan yang dilakukan peserta didik untuk 
162 Math Educa Journal Volume 2 No. 2 Edisi Oktober 2018, pp. $156-167$

setiap jenis koneksi matematis dapat dilihat pada tabel di bawah ini :

Tabel

\section{Kesalahan Koneksi Matematis Peserta Didik}

\begin{tabular}{|l|l|l|l|l|l|l|}
\hline \multirow{2}{*}{} & \multicolumn{2}{|l|}{$\begin{array}{l}\text { Koneksi antar } \\
\text { topik } \\
\text { matematika }\end{array}$} & \multicolumn{2}{l|}{$\begin{array}{l}\text { Koneksi } \\
\text { dengan } \\
\text { disiplin imu } \\
\text { lain }\end{array}$} & \multicolumn{2}{l|}{$\begin{array}{l}\text { Koneksi } \\
\text { matematika } \\
\text { dengan } \\
\text { kehidupan }\end{array}$} \\
\cline { 2 - 8 } & $\begin{array}{l}\text { Soal } \\
\text { No.1 }\end{array}$ & $\begin{array}{l}\text { Soal } \\
\text { No. } 2\end{array}$ & $\begin{array}{l}\text { Soal } \\
\text { No.3 }\end{array}$ & $\begin{array}{l}\text { Soal } \\
\text { No. } 4\end{array}$ & $\begin{array}{l}\text { Soal } \\
\text { No.5 }\end{array}$ & $\begin{array}{l}\text { Soal } \\
\text { No. } 6\end{array}$ \\
\hline JPDS & 1 & 10 & 18 & 23 & 23 & 26 \\
\hline Persen & 3,33 & 33,33 & 60 & 76,67 & 76,67 & 86,67 \\
\hline Rerata & \multicolumn{2}{|c|}{18,83} & \multicolumn{2}{|c|}{68,34} & \multicolumn{2}{|c|}{81,67} \\
\hline
\end{tabular}

Ket $:$ JPDS = Jumlah Peserta didik (melakukan kesalahan koneksi)

Berdasarkan tabel di atas terlihat bahwa kesalahan koneksi matematis antar topik dalam matematika ada 11 peserta didik yang melakukan kesalahan, khusus soal no 1 ada satu orang peserta didik yang melakukan kesalahan hal ini bisa berarti peserta didik cukup mampu menguasai konsep antar topik dalam matematika. Untuk soal no. 2 sepertiga atau 10 orang peserta didik melakukan kesalahan koneksi. Secara rata-rata untuk kesalahan koneksi antar topik dalam matematika terdapat 18,83 peserta didik melakukan kesalahan. Selanjutnya kesalahan koneksi matematika dengan disiplin ilmu lain lebih dari setengah jumlah peserta didik melakukan kesalahan ini dengan rata-rata 68,34. Kesalahan koneksi matematis yang paling banyak dilakukan peserta didik adalah kesalahan koneksi matematis dengan masalah dalam kehidupan sehari-hari dengan rata-rata 81,67, angka ini menyatakan lebih dari 75 persen dari jumlah peserta didik melakukan kesalahan. Berikut dijelaskan penyebab kesalahan koneksi yang dilakukan oleh peserta didik;

1. Kesalahan koneksi antar topik matematika

Secara umum kesalahan yang dilakukan peserta didik adalah kesalahan dalam menafsirkan keterangan dari soal, kesalahan dalam perhitungan, kesalahan dalam membuat kesimpulan terhadap jawaban soal yaitu hanya berhenti pada prosedur saja, tidak memberikan kesimpulan terhadap jawaban soal.

Penyebab kesalahan koneksi antar topik matematika yang dilakukan peserta didik adalah karena peserta didik kurang teliti dalam melihat keterangan soal, belum mampu menghubungkan pengetahuan-pengetahuan yang dimiliki untuk mengerjakan soal, peserta didik kurang teliti dalam perhitungan sehingga hasil akhir juga salah, kurang memahami konsep, lupa konsep yang telah dipelajari, dan tidak memahami maksud dari soal yang diberikan, dan terburu-buru dalam mengerjakan soal karena masih banyak soal yang harus diselesaikan.

Kesalahan koneksi antar topik matematika dapat diantisipasi dengan cara pendidik senantiasa mengkaitkan antara materi yang sedang dipelajari dengan materi prasyarat yang telah dipelajari sebelumnya, sehingga pemahaman peserta didik lebih mendalam dan lebih bertahan lama. Melalui koneksi matematis antara suatu materi dengan materi lainnya peserta didik dapat menjangkau beberapa aspek untuk penyelesaian masalah. Semakin banyak peserta didik melakukan koneksi 
matematis, maka akan semakin banyak pula ide matematis yang akan terbentuk.

2. Kesalahan koneksi antar displin ilmu lain

Secara umum kesalahan koneksi antar disiplin ilmu lain yang dilakukan peserta didik adalah kesalahan dalam menafsirkan keterangan dari soal, yaitu salah dalam menuliskan unsur-unsur yang diketahui dan yang ditanya dari soal, kesalahan dalam mengkaitkan konsep matematika dengan permasalahan yang diberikan yaitu belum bisa menentukan rumus apa yang sesuai untuk menyelesaikan masalah yang akan diselesaikan, kesalahan dalam mengkaitkan materi yang ada hubungannya dengan masalah yang akan diselesaikan yaitu belum bisa menentukan materi dalam matematika yang cocok dengan permasalahan yang akan diselesaikan.

Penyebab terjadinya kesalahan koneksi antar disiplin ilmu lain yang dilakukan peserta didik adalah karena kurang teliti dalam melihat keterangan soal, peserta didik belum mampu menghubungkan pengetahuan-pengetahuan yang dimiliki untuk mengerjakan soal karena peserta didik belum terbiasa mengerjakan soalsoal cerita dan kurang memiliki ketelitian dalam menyimak dan mengenali sebuah persoalan yang berkaitan dengan pokok bahasan tertentu karena pemahaman konsep matematika peserta didik masih kurang baik.

Untuk mengantisipsi berlanjutnya kesalahan yang dilakukan peserta didik, maka pendidik harus membuat koneksi antara pelajaran matematika dengan pelajaran lain sehingga peserta didik lebih mengenal manfaat matematika, karena matematika merupakan alat yang efisien dan diperlukan oleh semua ilmu pengetahuan, karena tanpa bantuan matematika semuanya tidak akan mendapatkan kemajuan yang berarti.

3. Kesalahan koneksi matematika dengan masalah dalam kehidupan sehari-hari

Secara umum kesalahan koneksi matematika dengan masalah dalam kehidupan sehari-hari yang dilakukan peserta didik adalah kesalahan dalam membuat model matematika dari permasalahan nyata yaitu salah dalam menafsirkan keterangan dari soal, kesalahan dalam memilih strategi dan aturan yang sesuai untuk menyelesaikan masalah yaitu belum bisa menentukan rumus apa yang akan digunakan untuk menyelesaikan masalah yang akan diselesaikan, kesalahan dalam mengkaitkan materi yang ada hubungannya dengan masalah yang akan diselesaikan yaitu belum bisa menentukan materi dalam matematika yang cocok untuk masalah yang akan diselesaikan.

Penyebab terjadinya kesalahan koneksi matematika dengan masalah dalam kehidupan sehari-hari yang dilakukan peserta didik adalah kesulitan dalam memaknai kalimat yang disajikan karena kurang cermat dalam membaca dan memahami kalimat demi kalimat, kurangnya tingkat penguasaan materi dan pengetahuan prasyarat peserta didik karena pemahaman konsep peserta didik masih kurang dan kurang memiliki ketelitian dalam menyimak dan mengenali sebuah persoalan 
164 Math Educa Journal Volume 2 No. 2 Edisi Oktober 2018, pp. 156-167

atau soal-soal yang berkaitan dengan pokok bahasan tertentu karena kurang terbiasa mengerjakan soal-soal cerita.

Kesalahan koneksi matematika dengan masalah dalam kehidupan sehari-hari dapat dihindari dengan cara pendidik membiasakan peserta didik untuk senantiasa mengkaitkan materi-materi dalam matematika dengan masalah-masalah kehidupan sehari-hari yang mungkin dialami peserta didik dengan memberikan contoh-contoh soal yang berkaitan dengan soal-soal kehidupan seharihari peserta didik sehingga peserta didik merasa bahwa matematika tidak hanya mata pelajaran yang berhubungan dengan angka saja, tetapi juga bermanfaat dalam membantu memecahkan persoalan dalam kehidupan sehari-hari peserta didik. Selain itu, diharapkan pendidik mampu merancang kegiatan pembelajaran yang dapat menfasilitasi kemampuan koneksi matematis peserta didik.

Apabila peserta didik sudah memahami bahwa matematika bisa memecahkan permasalahan dalam kehidupan sehari-hari, maka pemikiran dan wawasan peserta didik akan semakin terbuka dan luas terhadap matematika dan akan lebih mudah mengkaitkan permasalahan dalam kehidupan sehari-hari ke dalam bahasa matematika, peserta didik menjadi tahu pentingnya matematika karena terhubung dengan kehidupan atau lingkungan sekitar peserta didik sehingga pembelajaran akan lebih bermakna.

\section{KESIMPULAN DAN SARAN}

\section{Kesimpulan}

a. Kesalahan koneksi antar topik matematika.

1) Kesalahan dalam menafsirkan keterangan dari soal. Hal ini disebabkan karena peserta didik kurang teliti dalam melihat keterangan soal.

2) Kesalahan dalam mengkaitkan antar konsep-konsep dalam matematika. Hal ini disebabkan karena peserta didik belum mampu menghubungkan pengetahuan-pengetahuan yang dimiliki untuk mengerjakan soal.

3) Kesalahan dalam perhitungan. Hal ini disebabkan karena peserta didik kurang teliti dalam perhitungan sehingga hasil akhir juga salah.

4) Kesalahan dalam membuat kesimpulan terhadap jawaban soal yaitu hanya berhenti pada prosedur saja, tidak memberikan kesimpulan terhadap jawaban soal dan tidak menuliskan satuannya. Hal ini disebabkan karena peserta didik kurang memahami konsep, lupa konsep yang telah dipelajari, dan tidak memahami maksud dari soal yang diberikan.

b. Kesalahan koneksi antar disiplin ilmu lain.

1) Kesalahan dalam menafsirkan keterangan dari soal. Hal ini disebabkan karena peserta didik kurang teliti dalam melihat keterangan soal.

2) Kesalahan dalam mengkaitkan konsep matematika dengan permasalahan yang diberikan. Hal ini disebabkan karena 
peserta didik belum mampu menghubungkan pengetahuanpengetahuan yang dimiliki untuk mengerjakan soal.

3) Kesalahan dalam mengkaitkan materi yang ada hubungannya dengan masalah yang akan diselesaikan. Hal ini disebabkan karena peserta didik masih kurang memiliki ketelitian dalam menyimak atau mengenali sebuah persoalan atau soal-soal yang berkaitan dengan pokok bahasan tertentu.

c. Kesalahan koneksi matematika dengan masalah dalam kehidupan sehari-hari.

1) Kesalahan dalam membuat model matematika dari permasalahan nyata, yaitu salah dalam menafsirkan keterangan dari soal. Hal ini disebabkan karena peserta didik mengalami kesulitan dalam memaknai kalimat yang disajikan.

2) Kesalahan dalam memilih strategi dan aturan yang sesuai untuk menyelesaikan masalah. Hal ini disebabkan karena tingkat penguasaan materi dan pengetahuan prasyarat peserta didik masih kurang.

3) Kesalahan dalam mengkaitkan materi yang ada hubungannya dengan masalah yang akan diselesaikan. Hal ini disebabkan karena peserta didik kurang memiliki ketelitian dalam menyimak dan mengenali sebuah persoalan atau soal- soal yang berkaitan dengan pokok bahasan tertentu.

\section{Saran}

1. Pendidik diharapkan mampu merancang kegiatan pembelajaran yang dapat menfasilitasi kemampuan koneksi matematis peserta didik. Apabila peserta didik sudah memahami bahwa matematika bisa memecahkan permasalahan dalam kehidupan seharihari peserta didik maka peserta didik akan lebih mudah mengkaitkan permasalahan dalam kehidupan sehari-hari ke dalam bahasa matematika, sehingga peserta didik menjadi tahu pentingnya matematika dalam memecahkan persoalan kehidupan sehari-hari peserta didik sehingga pembelajaran menjadi lebih bermakna.

2. Pendidik senantiasa membiasakan peserta didik untuk selalu mengkaitkan materi-materi dalam matematika dengan masalah-masalah kehidupan sehari-hari yang mungkin dialami peserta didik sehingga peserta didik merasa bahwa matematika tidak hanya mata pelajaran yang berhubungan dengan angka saja, tetapi juga bermanfaat dalam membantu memecahkan persoalan dalam kehidupan sehari-hari peserta didik.

3. Pendidik senantiasa membuat koneksi antara pelajaran matematika dengan pelajaran lain sehingga peserta didik lebih 
mengenal manfaat matematika. Matematika merupakan alat yang efisien dan diperlukan oleh semua ilmu pengetahuan, karena tanpa bantuan matematika semuanya tidak akan mendapatkan kemajuan yang berarti.

4. Pendidik harus senantiasa mengkaitkan antara materi yang sedang dipelajari dengan materi prasyarat yang telah dipelajari sebelumnya sehingga pemahaman peserta didik lebih mendalam dan bertahan lama. Melalui koneksi matematis antara suatu materi dengan materi lainnya peserta didik dapat menjangkau beberapa aspek untuk penyelesaian masalah. Semakin banyak peserta didik melakukan koneksi matematis, maka akan semakin banyak pula ide matematis yang akan terbentuk.

5. Kepada peneliti selanjutnya diharapkan dapat mengembangkan penelitian ini pada setiap jenjang pendidikan, setiap mata pelajaran, setiap materi pelajaran dan menjadikan jawaban peserta didik dan jawaban pendidik dalam proses wawancara sebagai sumber data primer untuk mendapatkan data lebih valid dan akurat.

\section{REFERENSI}

Arifin, Zainal. 2011. Evaluasi Pembelajaran, Bandung: PT Remaja Rosdakarya.

. 2013. Evaluasi Pembelajaran, Bandung: PT Remaja Rosdakarya.
Arikunto, Suharsimi. 1993. Dasar-Dasar Evaluasi Pendidikan, Jakarta: PT Bumi Aksara. . 2006. Dasar-Dasar Evaluasi Pendidikan, Jakarta: PT Bumi Aksara. . 2007. Dasar-Dasar Evaluasi Pendidikan, Jakarta: PT Bumi Aksara. 2010. Dasar-Dasar Evaluasi Pendidikan, Jakarta: PT Bumi Aksara.

Baharuddin. 2010. Teori Belajar dan Pembelajaran, Yogyakarta: Ar-ruzz Media.

Dimyati dan Mudjiono. 2006. Belajar dan Pembelajaran, Jakarta: Rineka Cipta.

Emzir. 2009. Metodologi Penelitian Pendidikan Kuantitatif \& Kualitatif, Jakarta: PT Raja Grafindo Persada.

Fawaid, Ribatul Ahmad. 2015. Kemampuan Koneksi Matematik dalam Menyelesaikan Soal Bangun Ruang Sisi Datar Peserta didik Kelas IX SMP Islam Sunan Gunung Jati Ngunut Tulungagung Tahun Ajaran2015/2016. Skripsi.

Hamzah, Ali. 2014. Evaluasi Pembelajaran Matematika, Jakarta: PT Raja Gravindo Persada.

Harahap, Rosliana. 2012. Perbedaan Peningkatan Kemampuan Komunikasi dan Koneksi matematika Peserta didik Melalui Pembelajaran Kontekstual dengan Kooperatif Tipe STAD di SMP ALWashliyah 8 Medan. Jurnal.

Hurs, C. 2004. Numeracy in Action : Student Connecting Mathematical Knowledge to a Range of Contex. Mathematics: Essential Reseach Essential Practice, 1(1).

Nata, Abudin. 2012. Tafsir Ayat-Ayat Pendidikan, Jakarta: PT Raja Grafindo Persada.

National Council of Teachers of Mathematics (NCTM). 2000. Principles and Standars 
for School Mathematics. United States: Reston, VA author.

Pomalo, Amir. 2015. Analisis Kesalahan Peserta didik dalam Menyelesaikan Soal-Soal Operasi Campuran pada Materi Operasi Hitung Bilangan Bulat. Jurnal.

Pramesti, Getut. 2013. Analisis Kesalahan Peserta didik dalam Menyelesaikan Soal-Soal pada Materi Ruang Dimensi Tiga Ditinjau dari Gaya Kognitif Peserta didik. Jurnal.

Prawironegoro, Pratiknyo. 1985. Evaluasi Hasil Belajar Matematika Peserta didik Khusus Analisis Soal Untuk Bidang Studi Matematika, Jakarta: P2LLPTK

Puspitasari, N. 2011. Pembelajaran berbasis masalah dengan strategi kooperatif Jigsaw untuk meningkatkan kemampuan koneksi matematis siswa sekolah menengah pertama. Prosiding Seminar Nasional Pendidikan Matematika STKIP Siliwangi, Bandung.

Rahardjo, Swasono, dkk. 2016. Analisis Kemampuan Koneksi Matematis Peserta didik Kelas VIII pada Materi Teorema Pythagoras. Jurnal.

Rahayu, Alvina Mardi, dkk. 2016. Analisis Kesalahan Koneksi Matematis Peserta didik dalam Menyelesaikan Masalah Materi Bangun Datar Segi Empat. Jurnal.

Ramayulis. 2002. Ilmu Pendidikan Islam, Jakarta : Kalam Mulia.

Rismawati, Melida, dkk. 2016. Analisis Kesalahan Koneksi Matematis Peserta didik pada Materi Sistem Persamaan Linier Dua Variabel. Jurnal.

Rohendi, D \& Dulpaja J. 2003.Connected Mathematics Project (CMP) Model Based on Media to the Mathematical Connection Ability of Junior Hight School Student. Journal of Education and Practice, 4 (4).

Sanjaya, Wina. 2007. Penelitian Pendidikan, Jakarta: Prenada Media.
- 2013. Penelitian Pendidikan, Jakarta: Prenada Media.

Sarbani, Bambang. 2008. Standar Proses Pembelajaran Matematika. Artikel.

Sudjana, Nana. 2007. Penelitian dan Penilaian Pendidikan, Bandung: Sinar BaruAlgensindo.

. 2012. Penelitian dan Penilaian

Pendidikan, Bandung: Sinar Baru Algensindo.

Sudijono, Anas. 2005. Pengantar Evaluasi Pendidikan, Jakarta: PT Raja Grafindo Persada.

. 2008. Pengantar Evaluasi Pendidikan, Jakarta: PT Raja Grafindo Persada.

- 2011. Pengantar Evaluasi Pendidikan, Jakarta: PT Raja Grafindo Persada.

2015. Pengantar Evaluasi Pendidikan, Jakarta: PT Raja Grafindo Persada.

Sugiyono. 2010. Metode Penelitian Kuantitatif Kualitatif dan R\&D, Bandung: Alfabeta.

. 2012. Metode Penelitian Kuantitatif Kualitatif dan R\&D, Bandung: Alfabeta.

Suherman, H.L.E. 2003. Strategi pembelajaran matematika kontenporer (Rev.ed.). Bandung : JICA Universitaas Pendidikan Indonesia.

Sukmadinata. 2015. Metodologi Penelitian Pendidikan, Bandung: PT Remaja Rosdakarya.

Sumarmo, Utari. 2014. Asesmen Soft Skill dan Hard Skill Matematik Peserta didik dalam Kurikulum 2013. Makalah pada Seminar Pendidikan Matematika di Sekolah Tinggi Agama Islam Negeri Batu Sangkar. 